\title{
Medical responsibility in the climate crisis-the investment strategies of German Doctors' pension funds: a conflict between ethics and monetisation
}

\author{
Guido Schmiemann ${ }^{1,3}$, Christian Steuber ${ }^{2,3}$, Julia Gogolewska ${ }^{3}$, Dieter Lehmkuhl ${ }^{3}$, Christian M. Schulz ${ }^{3,4}$ \\ 'Department for Health Services Research, Institute for Public Health and Nursing Sciences, Bremen University, Bremen 28359, \\ Germany. \\ ${ }^{2}$ Pediatric Practice Bremen-Vegesack \& Klinikum Links der Weser, Bremen 28359, Germany. \\ ${ }^{3}$ KLUG - German Alliance for Climate Change and Health e.V., Hainbuchenstr. 10a, Berlin 13465, Germany. \\ ${ }^{4}$ Climate Change Working Group, Department of Anaesthesiology and Intensive Care, School of Medicine, Technical University \\ of Munich, Arcisstraße 21, München 80333, Germany.
}

Correspondence to: Dr. Guido Schmiemann, Department for Health Services Research, Institute for Public Health and Nursing Sciences, Bremen University, Grazer Str. 4, Bremen 28359, Germany. E-mail: schmiemann@uni-bremen.de

\begin{abstract}
How to cite this article: Schmiemann G, Steuber C, Gogolewska J, Lehmkuhl D, Schulz CM. Medical responsibility in the climate crisis-the investment strategies of German Doctors' pension funds: a conflict between ethics and monetisation. One Health Implement Res 2021;2:43-50. https://dx.doi.org/10.20517/ohir.2021.04
\end{abstract}

Received: 15 Apr 2021 First Decision: 10 Jun 2021 Revised: 18 Jun 2021 Accepted: 21 Jun 2021 First online: 22 Jul 2021

Academic Editor: Jorg Heukelbach Copy Editor: Yue-Yue Zhang Production Editor: Yue-Yue Zhang

\begin{abstract}
Energy production from fossil resources is a major contributor to the anthropogenic climate crisis. Many international medical organisations have therefore called for divestment, i.e., the withdrawal of capital from these industries. The capital investments of the physicians' pension funds in Germany amount to approximately 110 billion euros. Due to a lack of transparency, it is unclear to what extent environmental, social and governance criteria are applied to the allocation of investments. To protect human health, the climate impact of investments must be measured regularly and quantitatively (climate impact analysis). In addition, climate-related risks with respect to the returns on investment should be considered (climate risk analysis), when entire industrial sectors have to be re-organised. To ecologically and economically track the pathway to a zero-emission-portfolio, the outcome must be transparent for both the members and the public. This article summarises controversial issues discussed in this context with a focus on the situation and recent developments in Germany.
\end{abstract}


Keywords: Divestment, pension funds, medical ethics, climate change

\section{BACKGROUND}

Climate change is an existential threat to ecosystems on which economic prosperity and human health depend. As climate change is primarily caused by anthropogenic emissions of greenhouse gases, the British Medical Journal, the World Medical Association and some other major national medical associations have called for divestment, i.e., the withdrawal of capital from industries in the fossil energy sector and its associates $^{[1,2]}$. Divestment is considered to be a social tipping point for the necessary and extensive transformation process towards a climate-neutral economy that operates within planetary boundaries ${ }^{[3]}$.

Since planetary health and human health are inextricably linked, with human health being dependent upon planetary health, it has been suggested that the Hippocratic oath and its core tenet of primum nihil nocere be extended to encompass planetary health ${ }^{[4]}$. In recent years, the debate of the international health community on possibilities for action and medical ethics has also been taken up in the German health sector. The need for action and the potential benefits have already been formulated. For example, it has been estimated that, in Germany alone, 150,000 premature deaths could be prevented annually by 2040 if reduction plans were redesigned to be in full alignment with the Paris Climate Agreement ${ }^{[5]}$. The ethical aspect is already reflected in the present professional code of conduct of the German Medical Association ${ }^{[6]}$ : "Physicians have a special responsibility to participate in the preservation of the natural foundations of life with regard to their importance for human health".

Several national professional societies such as the German Association for Psychiatry, Psychotherapy and Psychosomatics (DGPPN), the German College of General Practitioners and Family Physicians (DEGAM) and the German Society of Anaesthesiology and Intensive Care Medicine (DGAI), as well as professional associations such as the Marburger Bund, the German Association of General Practitioners (DHV), the NAV-Virchow-Bund and the Young Doctors Association, have recognised their responsibility and formulated their own goals in position papers on climate protection and sustainability. Currently, the German Medical Association is urging all regional medical associations to sign a self-commitment, aiming for climate neutrality by 2030. Suggested actions include working on the sustainable investment strategies of pension funds. Of course, these actions are restricted to neither medical professional societies nor physicians. Other major players associated with the health care sector are the private health insurers. They hold capital of more than 350 billion euros in Germany. Among others, capital is invested in fossil fuels, tobacco, alcohol and pesticides ${ }^{[7]}$. Certain other professions (pharmacists, lawyers, architects, etc.) in Germany also manage their own pension funds. Therefore, the ideas presented can be applied to these professions as well.

In Germany, physicians are responsible for the investment strategies of around 110 billion euros through the state medical associations and their direct and indirect influence on the management of the pension funds ${ }^{[8]}$. The 122nd German Medical Assembly in 2019 called on the state medical associations and the medical pension funds to consider environmental, social and governance (ESG) criteria in their investments ${ }^{[9]}$. However, the discussion about the extent to which ESG criteria should be considered remains largely controversial ${ }^{[10]}$. These are the essential issues to be debated. 


\section{WHAT IS SUSTAINABLE INVESTMENT?}

\section{Identifying the issue}

There is no generally accepted definition of sustainable investment. The views range from climate neutrality of the portfolio to securing returns sufficient for an adequate pension. For this reason, the EU has been working on a taxonomy that defines and further develops strict and clear criteria for sustainability (sustainable finance) ${ }^{[1]]}$. Independent of this, pension funds can develop their own definitions of sustainability, formulate criteria and launch strategies for implementation. Different approaches can be used and combined: exclusion criteria (e.g., no investments in armament or fossil energy industries), best-in-class approach (investing in the leaders in their sectors), engagement approach (exercising voting rights to influence the company's policy) and impact investing (investing in a positive list, e.g., in renewable energies or manufacturing sustainable products). External service providers who manage capital for investing institutions, so-called asset managers, should be able to implement the sustainability criteria set by the institution.

Recent discussions and policies of an increasing number of investors focus on alignment of their portfolios with the $1.5^{\circ} \mathrm{C}$ target of the Paris climate agreement and with the UN sustainable development goals as essential part of their sustainable investment strategy.

\section{Recommendations for addressing this issue}

Ultimately, the formulated criteria are based on values that investors commit themselves to regarding their investments. In the case of pension funds, the members of the state medical associations or the chamber members delegated to the respective governing boards of the pension funds are eligible to determine those values. Additionally, to avoid harm caused by their investments and to consider prevention as a core principle of medical ethics, all physicians as members can request their pension fund to pledge, apply, monitor and report defined ESG criteria for all investments.

\section{HOW IS SUSTAINABILITY ASSESSED?}

\section{Identifying the issue}

The sustainability of an investment can only be properly assessed when all relevant information is fully disclosed. Currently, information on portfolios is only published in annual reports outlining the composition of the asset classes of shares, fixed-interest securities and real estate. The pension funds do not name exactly which shares, bonds or funds they are invested in, not even to their members, as they see this as endangering their business interests.

\section{Recommendations for addressing this issue}

However, since there is considerable pressure to rapidly reduce greenhouse gas emissions, it is necessary to quantify the $\mathrm{CO}_{2}$ (or greenhouse gas) footprint of the portfolio within the framework of a so-called climate impact analysis (using the XDC model or others ${ }^{[12-16]}$ ). The aggregated assessment of the portfolio, e.g., by an external service provider (research institute) or as a service of an asset manager, could be made transparent without disclosing individual investments of the portfolio. The business interests of the pension fund would not be jeopardised. Fund members should be updated annually on the ESG footprint of the investments made on their behalf and on changes to these impacts. They should also know which - if any - fossil fuel industries they are exposed to.

\section{Can pension funds influence the business model of fossil companies?}

Those who hold a very large number of shares in a company and organise majorities in shareholder meetings can try to influence the business model of companies (engagement approach). This requires very large stakes and cooperation with other shareholders pursuing the same agenda. The cost in time and effort 
is high and is therefore mostly carried out by service providers. Some regional funds, e.g., the ones in Bavaria, Berlin and Lower Saxony, pursue such an engagement approach. In its 2019 report, the Bayerische Versorgungskammer (Bavarian Chamber of Pensions) noted that capital is invested in the climatedamaging extraction of oil from tar sands, that the utilities' plans to phase out coal-fired power generation are not being implemented fast enough and that the climate targets of the oil-producing industry are not ambitious enough ${ }^{[16]}$. A recent study ${ }^{[17]}$ by the Transition Pathway Initiative, a global alliance of 87 investors, collectively responsible for 22.5 trillion USD in capital, came to the same conclusion. This clearly shows the limitations of the influence that can be exerted through this approach. Whether it can have any measurable success at all is completely unclear at this point in time.

Moreover, with regard to the fossil energy sectors, the fundamental question arises as to how "engagement" can be used to get the frogs to drain their own swamp. Therefore, in view of the planetary crisis, engagement can only have the goal of influencing the companies to set a climate neutrality target and to develop a path with verifiable milestones-otherwise, the capital must be withdrawn.

Others have claimed that divestment is nothing but "a grand gesture", i.e., a symbolic act, because responsible investors who divest from fossil fuels would be replaced by less responsible investors. This discussion was raised in the United Kingdom when institutions such as the Wellcome Trust and the University of Edinburgh declared why they would not divest. Their arguments have been analysed and disproved by David McCoy in a blog ${ }^{[18]}$. We agree with this analysis mainly for two reasons. First, there is evidence that divestment works when major companies such as Shell state that "It could have a material adverse effect on the price of our securities and our ability to access equity capital markets" ${ }^{\text {"[19] }}$. Second, divestment has not only a financial but also, even more importantly, a societal and political impact ${ }^{[20]}$. It signals that we are in the midst of transformation, and the very fact that professions with a high profile are supporting this movement can support further societal mobilisation.

\section{Does climate-friendly investing pay off?}

It is clear that assessing the sustainability of a portfolio costs money; however, the order of magnitude is in the tenth per cent range or even lower for large investment assets and does not significantly reduce the return. Depending on the business model, a service provider may be commissioned to assess the portfolio, or the management of the portfolio may be handed over to an asset manager, who implements the corresponding specifications of the pension funds with regard to ESG criteria.

There is growing evidence that sustainable investments are less risky than those that do not take ESG criteria into account. This was already shown in 2018 in a study by DWS (Deutsche Bank's asset management arm) with the University of Hamburg ${ }^{[21]}$. Current analyses show that the sustainable world stock index MSCI World SRI has been performing better than its conventional counterpart MSCI World for several years now ${ }^{[2]}$. One of the reasons for this is the energy sector. Producers of renewable energy have performed better than oil companies. The advantage was particularly evident during the COVID-19 crisis: both in the year before the outbreak of the pandemic and since the stock market crash in February 2020, the sustainable MSCI has performed better than the conventional MSCI. The Financial Times reported as recently as October 2020 that the major European oil companies lost 364 billion euros in market value last year, while the renewable energy sector made strong gains ${ }^{[23]}$. Sustainable funds have already performed better in the past: the 10-year average annual performance of 745 sustainable funds is $6.9 \%$, while that of 4150 traditional funds studied is only $6.3 \%^{[24]}$ 


\section{Why divestment?}

Fossil energy companies have a high risk of losing value drastically, as only a limited $\mathrm{CO}_{2}$ budget remains to achieve the Paris climate targets ${ }^{[2,26]}$. Around $80 \%$ of existing fossil fuel reserves would have to remain in the ground-in contrast to current business models-and the companies would therefore lose considerable value if climate protection measures were to be taken consistently. The risk of such a loss of value would considerably increase these companies' refinancing costs. Continuing to invest in fossil energy companies would thus be tantamount to betting that consistent climate policy will not take place. Divestment also serves to delegitimise this industry by publicly withdrawing capital from it and reinvesting this freed-up capital in climate-friendly solutions. This loss of value depends on, among other things, international climate policy, e.g., $\mathrm{CO}_{2}$ pricing and the availability of alternative energies, as well as the behaviour of other large investors. The latter can have a pull effect above a certain threshold ("herd instinct of the markets"), so that this sector loses considerable value within a short time and shares can only be sold at a great loss ("stranded assets").

More than 100 prominent international economists, including Nobel laureate Joseph Stiglitz, recently called for concrete divestment in an open letter from August 2020: "Institutions of financial power must end their fossil fuel investments and funding". Accordingly, investors should better invest their money in forwardlooking and stable sectors. The German Federal Financial Supervisory Authority (Bafin) has recognised the need to consider sustainability risks (climate risk analysis) and has written an information paper for financial institutions and banks to this effect ${ }^{[27]}$. The federal state authorities responsible for pension fund supervision have, however, to date barely encouraged professional funds to assess sustainability risks.

Overall, the withdrawal of capital from industries producing and marketing fossil fuels not only is medically imperative, but it should also increase the return and security of our investments. In the meantime, the Conference of Health Ministers of the federal states recommends to all actors in the healthcare system that capital investments also be oriented towards criteria of environmental and climate protection. The pension funds must therefore take climate risks into account and be accountable to their members. This holds true above all for the younger generation because it is their pensions and future that are primarily affected. Environmental sustainability must become a statutory objective, on an equal footing with return on investment, liquidity and diversity. This must apply to investments in all areas that could endanger people's health. Our health depends on functioning ecosystems and biodiversity ${ }^{[28]}$, as does at least $55 \%$ of global GDP. However, a fifth of countries are already at risk of ecosystem collapse in the near future, a new study by reinsurer Swiss ${ }^{[29]}$ warns.

There are several pension funds that are already well on the way to climate-friendly investments. Upon request, the authors can provide best-practice examples.

\section{Are there enough sustainable investments?}

This depends on the rigour of the standards and criteria. If you follow the "best-in-class" approach, i.e., to invest only in those companies that perform best in their industry in terms of sustainability, then there are no problems, because there is always a best. The market for sustainable investments is changing rapidly and more and more sustainable investments are coming onto the market. The European Green Deal, the orientation of many economic stimulus programmes towards sustainability (green recovery), the EU taxonomy of sustainable investments and the intention of German policymakers to make Germany a leading location for sustainable investments will significantly increase the supply of sustainable investments ${ }^{[30]}$. Since the sustainable orientation of a portfolio is, at any rate, done gradually, the share of sustainable investments may be adjusted step by step. 


\section{SUMMARY}

It is one of the fiduciary duties of pension funds to systematically record climate-related financial opportunities and risks (climate risk analysis). Investments in real estate, infrastructure, agribusiness and forestry can be exposed to "physical" risks from climate change itself, e.g., from extreme weather events. Business models based on the extraction or generation of energy from fossil fuels face "transition" risks arising from the politically desired and medically necessary move to a carbon-free economic model, e.g., effective $\mathrm{CO}_{2}$ pricing. At the same time, the structural change that is now taking place offers great investment opportunities.

The climate crisis not only affects the health directly but also by destroying ecosystems on which human health ultimately depends. The pension funds managed by us doctors must therefore quantify the impact of their investments on the climate. Furthermore, the disclosure of climate impacts is the basis for aligning capital investments with the goals of the Paris Climate Agreement, which is binding under international law. Commitment as the sole instrument for realising sustainability is not enough.

Physicians in no one country will save the world alone. However, they can take responsibility for their actions, even if their consequences become visible elsewhere or only in the future: not only global health, but also capital investments and economic prosperity are increasingly exposed to sustainability risks. Pension funds must therefore adequately consider climate-related financial risks and regularly publish the climate impact of their investments. In view of the more rapidly changing framework conditions, a debate on the investment policies of the medical pension funds is urgently required.

\section{DECLARATIONS}

\section{Acknowledgments}

The authors thank Anna and Garrett Stephens for help in language editing.

\section{Authors' contributions}

Drafted the manuscript: Schmiemann G, Schultz CM

Made substantial contributions to conception and design of the article: Steuber C, Gogolewska J, Lehmkuhl D

\section{Availability of data and materials}

Not applicable. A former version of this article has been published in German in a university repository: https://doi.org/10.26092/elib/483.

\section{Financial support and sponsorship}

None.

\section{Conflicts of interest}

All authors declared that there are no conflicts of interest.

\section{Ethical approval and consent to participate}

Not applicable.

\section{Consent for publication}

Not applicable. 


\section{Copyright}

(c) The Author(s) 2021.

\section{REFERENCES}

1. Abbasi K, Godlee F. Investing in humanity:. The BMJ ;368:m167. DOI PubMed

2. World Medical Association. WMA statement on divestment from fossil fuels. Available from: https://www.wma.net/policiespost/wma-statement-on-divestment-from-fossil-fuels/ [Last accessed on 25 Jun 2021].

3. Otto IM, Donges JF, Cremades R, et al. Social tipping dynamics for stabilizing Earth's climate by 2050. Proc Natl Acad Sci U S A 2020;117:2354-65. DOI PubMed PMC

4. Wabnitz K, Gabrysch S, Guinto R, et al. A pledge for planetary health to unite health professionals in the Anthropocene. Lancet 2020;396:1471-3. DOI PubMed PMC

5. Hamilton I, Kennard H, Mcgushin A, et al. The public health implications of the Paris Agreement: a modelling study. Lancet Planet Health 2021;5:e74-83. DOI PubMed PMC

6. German Medical Association. Professional code of conduct for physicians practicing in Germany. Available from: https://www.bundesaerztekammer.de/recht/berufsrecht/muster-berufsordnung-aerzte/muster-berufsordnung/ [Last accessed on 25 Jun 2021]. DOI

7. Schneider F, Gogolewska J, Ahrend KM, et al. Do private German health insurers invest their capital reserves of $€ 353$ billion according to environmental, social and governance criteria? J Med Ethics;2020:medethics-2020. DOI PubMed

8. Schulz CM, Ahrend K, Schneider G, Hohendorf G, Schellnhuber HJ, Busse R. Medical ethics in the Anthropocene: how are $€ 100$ billion of German physicians' pension funds invested? Lancet Planet Health 2019;3:e405-6. DOI PubMed

9. German Medical Association. 122 German medical congress - minutes, 2019. Available from: https://www.bundesaerztekammer.de/fileadmin/user_upload/downloads/pdf-Ordner/122.DAET/122DAETBeschlussprotokoll.pdf [Last accessed on 25 Jun 2021]. DOI

10. Hügler S. Divestment in physicians pension funds, investing in climate protection. Münchner Ärztliche Anzeigen ;2021:110:4-6. DOI

11. Commission E. Renewed sustainable finance strategy and implementation of the action plan on financing sustainable growth. Available from: https://ec.europa.eu/info/publications/sustainable-finance-renewed-strategy_en [Last accessed on 25 Jun 2021]. DOI

12. Helmke H, Hafner HP, Gebert F, Pankiewicz A. Provision of climate services-the XDC model. In: Leal Filho W, Jacob D, editors. Handbook of climate services. Springer International Publishing; 2020. p.223-49. DOI

13. GlobalanceWorld. Willkommen bei globalance world. Available from: https://fe.globalanceworld.com/de [Last accessed on 25 Jun 2021].

14. Assessment PACT. Available from: https://www.transitionmonitor.com/pacta-2020/ [Last accessed on 25 Jun 2021].

15. carbone 4. Climate impact of portfolios. Available from: https://www.carbone4.com/services_/climate-impact-portfolios/?lang=en [Last accessed on 25 Jun 2021]. DOI

16. Responsible Investment Bayerische Versorgungskammer. Available from: https://www.versorgungskammer.de/Portals/0/Media/Doku mente/Kapitalanlage/2019_Verantwortliches\%20Investieren\%20R\%C3\%BCckblick\%20reo.pdf. [Last accessed on 25 Jun 2021] (in German). DOI

17. Gardiner D, Sullivan R, Dietz S, Jahn V. The oil and gas industry will need to scale back much faster to limit warming to $1.5^{\circ} \mathrm{C}$. Available from: https://www.transitionpathwayinitiative.org/publications/48?type=NewsArticle [Last accessed on 25 Jun 2021]. DOI

18. McCoy D. Divestment is no grand gesture. Available from: https://blogs.bmj.com/bmj/2015/07/30/david-mccoy-divestment-is-nogrand-gesture/ [Last accessed on 25 Jun 2021]. DOI

19. Carrington D. Fossil fuel divestment funds rise to \$6tn. Available from: https://www.theguardian.com/environment/2018/sep/10/fossilfuel-divestment-funds-rise-to-6tn [Last accessed on 25 Jun 2021]. DOI

20. Otto IM, Donges JF, Cremades R, et al. Social tipping dynamics for stabilizing Earth's climate by 2050. Proc Natl Acad Sci U S A 2020;117:2354-65. DOI PubMed PMC

21. Busch T, Friede G. The robustness of the corporate social and financial performance relation: a second-order meta-analysis: corporate social and financial performance. Corp Soc Responsib Environ Mgmt 2018;25:583-608. DOI

22. MSCI ACWI sustainable impact index (USD). Available from: https://www.msci.com/documents/10199/6d2b3e68-90e0-448e-bd52eaf0397539d1 [Last accessed on 25 Jun 2021].

23. Raval A, Hume N. European oil stocks dealt $€ 360$ bn blow while renewables surge. Available from: https://www.ft.com/content/4eb74a22-5c2d-4cfa-ab30-980e669c8c88 [Last accessed on 25 Jun 2021].

24. Collinson P. Ethical investments are outperforming traditional funds. Available from: https:/www.theguardian.com/money/2020/jun/13/ethical-investments-are-outperforming-traditional-funds [Last accessed on 25 Jun 2021]. DOI

25. Rogelj J, Forster PM, Kriegler E, Smith CJ, Séférian R. Estimating and tracking the remaining carbon budget for stringent climate targets. Nature 2019;571:335-42. DOI PubMed

26. Steffen W, Rockström J, Richardson K, et al. Trajectories of the earth system in the anthropocene. Proc Natl Acad Sci U S A 2018;115:8252-9. DOI PubMed PMC

27. Federal Financial Supervisory authority - guidance notice on dealing with sustainability risks. Available from: https://www.bafin.de/SharedDocs/Downloads/DE/Merkblatt/d1_mb_Nachhaltigkeitsrisiken.html [Last accessed on 25 Jun 2021]. DOI

28. Myers SS. Planetary health: protecting human health on a rapidly changing planet. Lancet 2017;390:2860-8. DOI PubMed 
29. Swiss Re. A fifth of countries worldwide at risk from ecosystem collapse as biodiversity declines, reveals pioneering Swiss Re index. 2020 Available from: https://www.swissre.com/media/news-releases/nr-20200923-biodiversity-and-ecosystems-services.html [Last accessed on 25 Jun 2021]. DOI

30. German Government SFBd. Shifting the trillions - a sustainable finance system 2021. Available from: https://sustainable-financebeirat.de/wp-content/uploads/2021/02/210224_SFB_-Abschlussbericht-2021.pdf (in German) [Last accessed on 25 Jun 2021]. 